\title{
The first estimates of global nucleation mode aerosol concentrations based on satellite measurements
}

\author{
M. Kulmala ${ }^{1}$, A. Arola ${ }^{2}$, T. Nieminen ${ }^{1}$, L. Riuttanen ${ }^{1}$, L. Sogacheva ${ }^{3}$, G. de Leeuw ${ }^{1,3}$, V.-M. Kerminen ${ }^{1,3}$, and \\ K. E. J. Lehtinen ${ }^{2,4}$ \\ ${ }^{1}$ Department of Physics, University of Helsinki, P.O. Box 64, 00014 University of Helsinki, Finland \\ ${ }^{2}$ Finnish Meteorological Institute, Kuopio Unit, P.O. Box 1627, 70211 Kuopio, Finland \\ ${ }^{3}$ Finnish Meteorological Institute, Climate Change Unit, P.O. Box 503, 00101 Helsinki, Finland \\ ${ }^{4}$ Department of Applied Physics, University of Eastern Finland, P.O. Box 1627, 70211 Kuopio, Finland
}

Received: 26 May 2011 - Published in Atmos. Chem. Phys. Discuss.: 1 July 2011

Revised: 29 September 2011 - Accepted: 22 October 2011 - Published: 2 November 2011

\begin{abstract}
Atmospheric aerosols play a key role in the Earth's climate system by scattering and absorbing solar radiation and by acting as cloud condensation nuclei. Satellites are increasingly used to obtain information on properties of aerosol particles with a diameter larger than about $100 \mathrm{~nm}$. However, new aerosol particles formed by nucleation are initially much smaller and grow into the optically active size range on time scales of many hours. In this paper we derive proxies, based on process understanding and ground-based observations, to determine the concentrations of these new particles and their spatial distribution using satellite data. The results are applied to provide seasonal variation of nucleation mode concentration. The proxies describe the concentration of nucleation mode particles over continents. The source rates are related to both regional nucleation and nucleation associated with more restricted sources. The global pattern of nucleation mode particle number concentration predicted by satellite data using our proxies is compared qualitatively against both observations and global model simulations.
\end{abstract}

\section{Introduction}

Atmospheric aerosol particles affect the quality of our life in many different ways. First of all, they influence the Earth's radiation balance directly by scattering and absorbing solar radiation, and indirectly by acting as cloud condensation nuclei (e.g. Forster et al., 2007; Myhre, 2009; Quaas

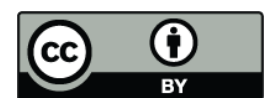

Correspondence to: M. Kulmala (markku.kulmala@helsinki.fi) et al., 2009). Secondly, aerosol particles modify the intensity and properties of radiation reaching the Earth's surface, having direct influences on the vegetation and its interactions with the carbon cycle and atmospheric chemistry ( $\mathrm{Gu}$ et al., 2002; Wang et al., 2008). Thirdly, aerosol particles deteriorate human health and reduce visibility in urban areas (Pope and Dockery, 2006; Hand and Malm, 2007; Anderson, 2009). The various effects of atmospheric aerosol particles are tightly connected via physical, chemical, meteorological and biological processes occurring in the atmosphere and at the atmosphere-biosphere interface (e.g. Arneth et al., 2010). In addition these natural processes and feedbacks, the couplings between atmospheric aerosol particles, trace gases, air quality and climate are affected by human actions, such as emission policy, forest management and land use change (Brasseur and Roeckner, 2005; Arneth et al., 2009; Jacob and Winner, 2009; Raes et al., 2010).

Quantifying the climatic, health and other effects of atmospheric aerosol particles requires detailed information on their physical and chemical properties as well as on their spatial and temporal variability in the atmosphere. Detailed aerosol properties can only be measured in situ, and a few ground-based measurement networks for this purpose have been established. These include the Global Atmospheric Watch (GAW) aerosol program (http://www.wmo. int/gaw/sag/aerosol) and the global AERONET network of ground-based sun photometers (http://aeronet.gsfc.nasa.gov/ new_web/system_descriptions_operation.html) as well as various regional networks, such as the European Monitoring and Evaluation Programme EMEP (http://www.emep.int/), EUSAAR (Philippin et al., 2009), and the US Interagency Monitoring of Protected Visual Environments IMPROVE (http://vista.cira.colostate.edu/improve/). Information on the

Published by Copernicus Publications on behalf of the European Geosciences Union. 
vertical structure of aerosol properties can be obtained from aircraft, balloon and lidar measurements and from model simulations. Remote sensing with satellite instruments provide aerosol data over large spatial areas, but the information is limited to particles in the optically-active size range, i.e. particles larger than about $100 \mathrm{~nm}$ in diameter. Passive instruments on satellites are currently able to provide columnintegrated aerosol properties, such as the aerosol optical depth (AOD) at several wavelengths, and space-born lidars provide vertical profile information on a global scale. Some instruments provide also microphysical properties such as the fine and coarse mode fraction, effective radius, and information on particle shape or aerosol components (see e.g. Kokhanovsky and de Leeuw, 2009 and de Leeuw et al., 2011 for a comprehensive overview of satellite capabilities). Instruments with multiple viewing angles provide information on vertical structures in volcanic ash and fire plumes (e.g. Kahn et al., 2007, 2008; Muller et al., 2007).

A key phenomenon associated with the atmospheric aerosol system is the nucleation and subsequent growth of nucleated aerosol particles. Field measurements have demonstrated nucleation to be a frequent phenomenon in the continental boundary layer, as well as in the free troposphere (Kulmala and Kerminen, 2008, and references therein; Manninen et al., 2010). Direct observational evidence has been obtained that particles nucleated in the atmosphere are able to grow into cloud condensation nuclei $(\mathrm{CCN})$ sizes $(\mathrm{Li}-$ havainen et al., 2003; Laaksonen et al., 2005; Wiedensohler et al., 2009) and participate in cloud droplet formation (Kerminen et al., 2005). Global model simulations suggest that nucleation is very likely the dominant source of particles in terms of their number concentration in the global atmosphere (Spracklen et al., 2006, 2010; Yu et al., 2010), and a significant contributor to global CCN concentrations (Spracklen et al., 2008; Merikanto et al., 2009; Pierce and Adams, 2009; $\mathrm{Yu}$ and Luo, 2009). As a result, nucleation has the potential to influence cloud properties and global radiative forcing (Wang and Penner, 2008; Makkonen et al., 2009; Merikanto et al., 2010; Kazil et al., 2010).

Combination of satellite data with either model simulations or in situ observations has been successfully used in several applications, including surface air quality predictions (e.g. Martin, 2008; Hoff and Christopher, 2009), evaluation of emission inventories (e.g. Lamsal et al., 2011; Lee et al., 2011), and constraining the radiative effects by aerosols (e.g. Myhre, 2009). Our understanding on atmospheric nucleation relies essentially on field and laboratory experiments, theoretical calculations and model studies (Kerminen et al., 2010), with practically no use of satellite data. Satellite measurements of nucleated particles are complicated by their relatively slow growth to optically active sizes in the atmosphere (e.g. Tunved et al., 2006). Therefore, alternative methods to trace these particles on regional and global scales using satellite data need to be explored.
In this paper we propose the use of proxies, i.e. parameterizations for the concentrations of nucleated particles in terms of satellite-observable quantities. These proxies are developed based on our best understanding on the atmospheric nucleation and growth processes. To the extent possible, the proxies are evaluated using detailed information from longterm ground-based measurements. The considered proxies describe the total number concentration of nucleation mode particles, that is, particles smaller than about $25-30 \mathrm{~nm}$ in diameter. Our emphasis is put on the continental boundary layer, since nucleation in that region is both more active and better understood than nucleation taking place over marine areas (Vuollekoski et al., 2009; Kazil et al., 2010; O'Dowd et al., 2010). In terms of the global aerosol number budget, free-troposphere nucleation is probably extremely important as well (e.g. Merikanto et al., 2009), but our approach is not suitable for tracing particles formed in that region due to long times scales associated with the life cycle of these particles.

\section{Proxies for nucleation mode particle number concentrations}

The balance equation for the particle concentration in the nucleation mode, $N_{\text {nuc }}$, can be written as

$\frac{d N_{\text {nuc }}}{d t}=J-N_{\text {nuc }} \times$ CoagS,

where $J$ is the nucleation rate and CoagS is the average coagulation sink for the nucleation mode (Kulmala et al., 2001). The nucleation rate can be connected to the gas-phase concentration of the nucleating vapour, $C$, via the following general relation:

$J=K_{\text {nuc }} \times C^{n}$.

Here $K_{\text {nuc }}$ is the so-called nucleation coefficient and the exponent $n$ is related to the nature of the nucleation mechanism (McMurry and Friedlander, 1979; Kulmala et al., 2006). The nucleation coefficient takes into account the effect of factors other than the vapour driving the nucleation rate, including the ambient temperature and relativity humidity and the presence of impurities (trace gases, ions) that influence the stability of nucleating clusters. The vapors dictating the nucleation rate are expected be of extremely low volatility, so their gasphase concentration can be approximated by the relation

$\frac{d C}{d t}=Q-C \times \mathrm{CS}$.

Here $Q$ is the source rate of vapour $C$ due to chemical reactions and CS is the condensation sink (Kulmala et al., 2001).

In the following we derive proxies for the nucleation mode particle number concentration, $N_{\text {nuc }}$, in two different situations of boundary-layer nucleation: (1) regional nucleation driven by photochemistry and occurring typically over spatial scales of hundreds of kilometers (Kulmala and Kerminen, 
2008), and (2) primary nucleation that takes place in the immediate vicinity of highly localized sources, or at scales substantially smaller than those resolved by large-scale modeling frameworks (Luo and Yu, 2011). We also discuss how to apply these proxies when relying on satellite measurements.

\subsection{Regional atmospheric nucleation}

The times scales, over which the nucleation mode particle number concentration and nucleating vapour concentration reach a pseudo-steady state with respect to sources and sinks is equal to the inverse of CoagS and CS, respectively (Kerminen et al., 2004). In regional nucleation, the assumption of such a steady state is reasonable. By setting the left hand side of Eqs. (1) and (3) equal to zero, indicative of the pseudosteady state, and by combining Eqs. (1) to (3), we obtain:

$N_{\text {nuc }}=K_{\text {nuc }} \frac{Q^{n}}{\mathrm{CS}^{n} \operatorname{CoagS}}$.

For nucleation mode particles having a mean diameter of $d_{\text {nuc }}$, the coagulation sink is proportional to the condensation sink via the following relation (Lehtinen et al., 2007):

$\operatorname{CoagS}\left(d_{\text {nuc }}\right)=\operatorname{CS}\left(\frac{d_{\mathrm{v}}}{d_{\text {nuc }}}\right)^{m}$.

Here $d_{\mathrm{v}}$ is the diameter of the condensing vapor molecule, i.e. the vapor for which the value of CS is determined, and the exponent $m$ varies between about 1.5 and 1.9 depending on the shape of the pre-existing particle number size distribution. The mean diameter of the nucleation mode, $d_{\text {nuc }}$, varies with time. By noting this and combining Eqs. (4) and (5), we then obtain:

$N_{\text {nuc }}=K \frac{Q^{n}}{\operatorname{CS}^{n+1}}$.

The factor $K$ now carries the information on both the nucleation coefficient and the size-dependent relation between CoagS and CS according to Eq. (5).

Atmospheric observations (Riipinen et al., 2007; Kuang et al., 2008; Paasonen et al., 2010), as well as recent laboratory measurements (Metzger et al., 2010; Sipilä et al., 2010), suggest that the nucleation rate scales to the power 1-2 of the nucleating vapor concentration. In most cases a clear correlation between $J$ and $C$ is obtained by assuming sulphuric acid to be the sole driver of the nucleation process, whereas in some cases an additional vapour, most likely an organic one, is needed (Paasonen et al., 2010). Gaseous sulphuric acid (SA) is produced by the oxidation of sulfur dioxide with the hydroxyl radical:

$Q_{\mathrm{SA}}=k_{1}[\mathrm{OH}]\left[\mathrm{SO}_{2}\right]$,

whereas condensing organic vapors can be produced by multiple oxidants (Kroll and Seinfeld, 2008). There are some indications, however, that the organics most likely to participate in nucleation (NUCORG) are those formed preferably by the $\mathrm{OH}$-initiated oxidation of organic precursor compounds, ORG (Hao et al., 2009):

$$
Q_{\mathrm{NUCORG}}=k_{2}[\mathrm{OH}][\mathrm{ORG}] \text {. }
$$

The gaseous $\mathrm{OH}$ concentration, rarely available from measurements, is usually directly proportional to the ultraviolet radiation intensity, UV, in the lower troposphere (Rohrer and Berresheim, 2006). The performance of UV as a proxy for the $\mathrm{OH}$-initiated oxidation of $\mathrm{SO}_{2}$ has been demonstrated by comparing predicted and measured gaseous sulphuric acid concentrations (Petäjä et al., 2009).

By setting the exponent $n$ to either 1 or 2, by assuming that $[\mathrm{OH}]$ is proportional to UV, and by combining Eqs. (6), (7) and (8), we obtain four potential proxies for $N_{\text {nuc }}$ :

$$
\begin{aligned}
& N_{n, 1}=\frac{\mathrm{UV}\left[\mathrm{SO}_{2}\right]}{\mathrm{CS}^{2}}, \\
& N_{n, 2}=\frac{\mathrm{UV}^{2}\left[\mathrm{SO}_{2}\right]^{2}}{\mathrm{CS}^{3}}, \\
& N_{n, 3}=\frac{\mathrm{UV}[\mathrm{ORG}]}{\mathrm{CS}^{2}}, \\
& N_{n, 4}=\frac{\mathrm{UV}^{2}[\mathrm{ORG}]^{2}}{\mathrm{CS}^{3}} .
\end{aligned}
$$

In analyzing field measurements we may apply the proxies (9) and (10) as such, whereas proxies (11) and (12) require estimation of either the organic precursor vapor concentration, [ORG], or the concentration of organic vapors participating in nucleation and very initial growth of the nuclei, [NUCORG]. If the latter quantity is used, the proxies (11) and (12) will be reduced to the following forms: $N_{n, 3}=[\mathrm{NUCORG}] / \mathrm{CS}, N_{n, 4}=[\mathrm{NUCORG}]^{2} / \mathrm{CS}$. The value of [NUCORG] can be derived from measured nuclei growth rates within a factor of about 2 (Paasonen et al., 2010).

\subsection{Primary nucleation}

The steady-state assumptions made in the previous subsection are no longer valid for primary nucleation because the nucleation process can be extremely rapid, as it is in case of vehicular emissions, or because the nucleating air parcels are diluted very rapidly (Kerminen et al., 2004). In urban areas with primary nucleation resulting from traffic exhaust, concentrations of nucleation mode particles have been observed to correlate with nitrogen dioxide $\left(\mathrm{NO}_{2}\right)$ concentrations (e.g. Fernandez-Camacho, 2010). When spread over larger volumes of ambient air, primary nuclei are expected to be scavenged by pre-existing larger particles according to Eq. (1). By assuming a steady state for this process we obtain

$N_{n, 5}=\frac{\left[\mathrm{NO}_{2}\right]}{\mathrm{CS}}$. 
This is a potential proxy for primary nucleated particles resulting from traffic emissions, or any other combustion sources that both emit significant amounts of nitrogen oxides and initiate primary nucleation in the atmosphere.

In large-scale models, a fraction of the sulfur emissions related to anthropogenic combustion sources is assumed to be in the form of primary particles and a fraction of these particles are often assumed to be nucleation mode particles resulting from sub-grid scale nucleation (see Luo and Yu, 2011, and references therein). By applying the same reasoning as above, the following satellite proxy for these nuclei can be derived:

$N_{n, 6}=\frac{\left[\mathrm{SO}_{2}\right]}{\mathrm{CS}}$.

This is a potential proxy primary nuclei associated with strong $\mathrm{SO}_{2}$ emitters such some coal-fired power plants and smelters.

\subsection{Satellite applications}

In case of satellite measurements, the proxies given by Eqs. (9) to (14) need to be simplified further. To start with, we need to replace $\mathrm{CS}$ with a proper column-integrated quantity. Here we propose the aerosol optical depth (AOD) for this purpose for several reasons. First, the satellite-derived AOD has been successfully used to trace surface particulate matter concentrations in air quality applications (Hoff and Christopher, 2009), in addition to which it has turned out to be a good tracer for atmospheric cloud condensation nuclei concentrations (Andreae, 2009). Second, both vapor condensation and light scattering are roughly proportional to the aerosol surface area distribution. The relatively good correlation between CS and aerosol light scattering coefficient has been confirmed by field measurements (Virkkula et al., 2011). Third, due to their similar dependence on the particle size, CS and AOD are expected to respond to changes in the ambient relative humidity in a similar manner. The apparent drawback with our approach is that as a columnintegrated property AOD is unable to take into account the influence of mixed-layer height on CS, nor the effects of elevated aerosol layers on the relation between CS and AOD. The performance of replacing CS with AOD will be investigated in Sect. 3.1.

Observation of sulfur dioxide by satellites is extremely challenging and usually limited to strongly polluted regions and major plumes originating from power plants, smelters or volcanic eruptions (see Veefkind et al., 2011, and references therein). Compared with $\mathrm{SO}_{2}$, satellite measurements of $\mathrm{NO}_{2}$ column burdens typically encountered in the lower troposphere are much more accurate. The connection between $\mathrm{NO}_{2}$ and $\mathrm{AOD}$, as retrieved from satellites, has been shown to reflect different aerosol source types to be consistent with the corresponding connection obtained from global model simulations (Veefkind et al., 2011).
Few organic compounds can be detected with satellite instruments, and the only one having a clear association with organic aerosol precursors is formaldehyde (HCHO). Column retrievals of $\mathrm{HCHO}$ have been successfully used to constrain non-methane hydrocarbon emissions from biogenic and biomass burning sources (Stavrakou et al., 2009) and, in some cases, to trace secondary organic aerosol concentrations (Veefkind et al., 2011). These findings suggest that it might be possible to derive [ORG] in the proxies given by Eqs. (11) and (12) using satellite data on HCHO. Before doing that, however, the potential connection between $\mathrm{HCHO}$ and ORG should be investigated by in situ field measurements.

The above discussion points out that neither $\left[\mathrm{SO}_{2}\right]$ nor [ORG] are usually available from satellite measurements. One, yet by no means ideal, solution for this problem is to remove these two quantities from the proxies given by Eqs. (9) to (12) by setting them constant, which is equal to assuming that it is photochemistry rather than the exact concentration of any trace gas that dictates the nucleation rate. We will discuss the consequences of this very crude approximation in Sects. 3.1 and 3.2.

\section{Evaluation and preliminary results}

In this section, we evaluate selected proxies against in situ field measurements and then apply them on the global scale using satellite retrievals. The main purpose of the evaluation, conducted in Sect. 3.1, is to find out how critical it is to have knowledge on the $\mathrm{SO}_{2}$ concentration when applying the proxy given by Eq. (9), and whether replacing CS with AOD can be considered reasonable. In Sect. 3.2 we investigate the potential of using satellite-derived column $\mathrm{SO}_{2}$ and $\mathrm{NO}_{2}$ concentrations in association with our proxies and, most importantly, discuss the overall performance of the proxy given Eq. (9) in the global atmosphere after setting the $\mathrm{SO}_{2}$ concentration constant and replacing CS with AOD.

\subsection{Evaluation of selected proxies against in situ measurements}

The ground-based data used in this work were obtained from measurements at the SMEAR II station in Hyytiälä, Southern Finland, located in the boreal forest (Hari and Kulmala, 2005). Size distributions of 3-1000 nm particles have been measured at the SMEAR II station continuously since 1996 (e.g. Kulmala et al., 2010). From these data we obtain both the nucleation mode particle number concentration, as well as the condensation sink (see Table 1). Here we take nucleation mode particles to be all particles smaller than $25 \mathrm{~nm}$ in mobility diameter. Condensation sink is calculated from the number size distributions according to the method presented in Kulmala et al. (2001) accounting for particle hygroscopic growth according to the parameterization by Laakso 
Table 1. Mean, median and percentiles (10th and 90th) for the measured data set used in the comparison of proxy performance in Hyytiälä. Measured nucleation mode particle concentrations $N_{\text {nuc }}$ were compared to Eq. (9) (proxy utilizing UVB, $\mathrm{SO}_{2}, \mathrm{CS}$ and AOD). The comparisons are shown in Figs. 1 and 2. In the comparisons data was averaged to $30 \mathrm{~min}$ time resolution.

\begin{tabular}{lrrrr}
\hline & mean & median & $\begin{array}{r}\text { 10th } \\
\text { percentile }\end{array}$ & $\begin{array}{r}\text { 90th } \\
\text { percentile }\end{array}$ \\
\hline$N_{\text {nuc }}\left(\mathrm{cm}^{-3}\right)$ & 1100 & 320 & 53 & 2730 \\
$\mathrm{UVB}\left(\mathrm{W} \mathrm{m}{ }^{-2}\right)$ & 0.45 & 0.63 & 0.20 & 2.02 \\
$\mathrm{SO}_{2}(\mathrm{ppb})$ & 0.18 & 0.10 & 0.03 & 0.36 \\
$\mathrm{CS}\left(10^{-3} \mathrm{~s}^{-1}\right)$ & 3.4 & 2.7 & 1.0 & 5.9 \\
$\mathrm{AOD}$ & 0.10 & 0.09 & 0.05 & 0.18 \\
\hline
\end{tabular}

et al. (2004). SO $\mathrm{SO}_{2}$ concentration has been measured continuously since 1996 by a fluorescence analyser (TEI 43 BS, Thermo Environmental, Franklin, MA, USA). The detection limit of the instrument is $0.1 \mathrm{ppb}$.

Aerosol optical depth measurements were started at the SMEAR II station in February 2008. They are part of the global AERONET network of ground-based sun photometers (Holben et al., 1998). AOD is measured at 8 different wavelengths, and here we use the wavelength of $500 \mathrm{~nm}$ as this is closest to the satellitebased observations used in the global proxies. The sequence of measurements, from which AOD and aerosol microphysical parameters are derived, is described at the AERONET webpage (http://aeronet.gsfc.nasa.gov/new_web/ system_descriptions_operation.html). Sun photometer observations are available only when the air mass, i.e. the optical path length through the atmosphere, is equal to 7 or less. Due to the northern location of Hyytiälä, this excludes the AOD data availability from about mid-November to mid-February.

Figure 1 (left panel) shows the comparison between measured nucleation mode particle number concentrations and those derived from the proxy given by Eq. (9) based on 22 months of in situ measurements during 2008-2010 at the SMEAR II station. The two quantities are positively correlated $(r=0.54)$, but there is also lot of scatter in the data points. The main reason for the scatter in this figure is likely that the proxy assumes a very simple dependence of the nucleation rate, $J$, on trace gas concentrations and environmental conditions (nucleating vapour is sulphuric acid; $K_{\text {nuc }}$ is constant and $n=1$ in Eq. 2). In reality, the value of $n$ has been found to be somewhere between 1 and 2 at SMEAR II and elsewhere, whereas the value of $K_{\text {nuc }}$ may vary up to an order of magnitude between individual nucleation events at any particular site (Riipinen et al., 2007; Kuang et al., 2008; Paasonen et al., 2010). Another reason for the scatter is the relatively strong dependence of the nuclei removal rate by coagulation on the nuclei size (Eq. 5). This makes the life
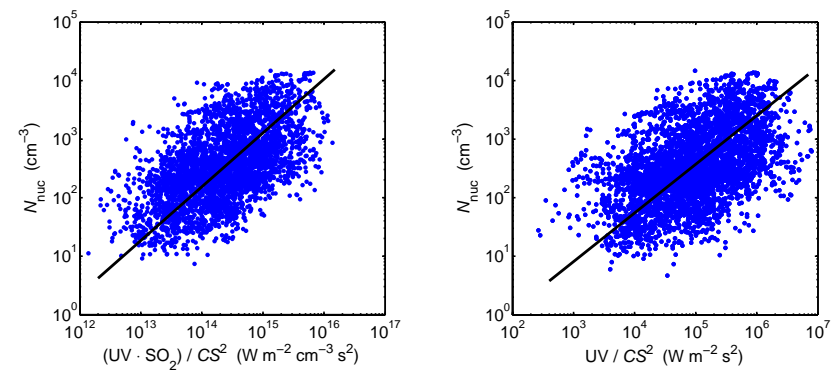

Fig. 1. Measured number concentration of nucleation mode particles $\left(N_{\text {nuc }}\right.$, diameter $3-25 \mathrm{~nm}$ ) as a function of the proxy given by Eq. (9) (left) and the same proxy with $\mathrm{SO}_{2}$ concentration left out (right). Each data point represents $30 \mathrm{~min}$ averaged data. The black lines show linear least-squares fit to the data points. Left: $\log (y)=0.92 \times \log (x)-10.69(r=0.54, p<0.001)$; Right: $\log (y)=0.83 \times \log (x)-1.58(r=0.49, p<0.001)$.

time and thereby the concentration of nucleation mode particles sensitive to their growth rate. Nuclei growth rates have been observed to vary by a factor of about $2-5$ at individual measurement sites (e.g. Manninen et al., 2010).

If we neglect the influence of $\mathrm{SO}_{2}$ concentration variations on our proxy, i.e. when we set $\left[\mathrm{SO}_{2}\right]$ to be constant in Eq. (9), the correlation between the measured and proxy-derived nucleation mode particle number concentration decreases only slightly from 0.54 to 0.49 (Fig. 1, right panel). The relatively moderate influence of $\mathrm{SO}_{2}$ on the performance of the proxy might appear surprising, given the strong association between the nucleation rate and gaseous sulphuric acid concentration observed at the SMEAR II station (Riipinen et al., 2007; Nieminen et al., 2009). On the other hand, this finding reflects the complexity by which the nucleation mode particle number concentration depends on the combination of the whole photochemistry (UV radiation intensity) and sinks for both nucleated particles and their precursor vapours (CS). Although knowing the exact magnitude of the $\mathrm{SO}_{2}$ concentration appears not to be crucial at the SMEAR II station, we would like to stress here that the situation may be totally different in regions having either exceptionally high or very low $\mathrm{SO}_{2}$ concentration levels.

Perhaps the most crucial of our assumptions is to replace $\mathrm{CS}$ with AOD. Figure 2 demonstrates how this replacement affects the performance of our proxy in case of our in situ measurements. The correlation between the measured and proxy-derived nucleation mode particle number concentrations reduces now down to 0.25 when the $\mathrm{SO}_{2}$ concentration is taken into account and to 0.23 when it is not. We may conclude that while our solution to replace CS with AOD is necessary in order to apply the proxies to a global scale using satellite data, it is clearly not the ideal one. 

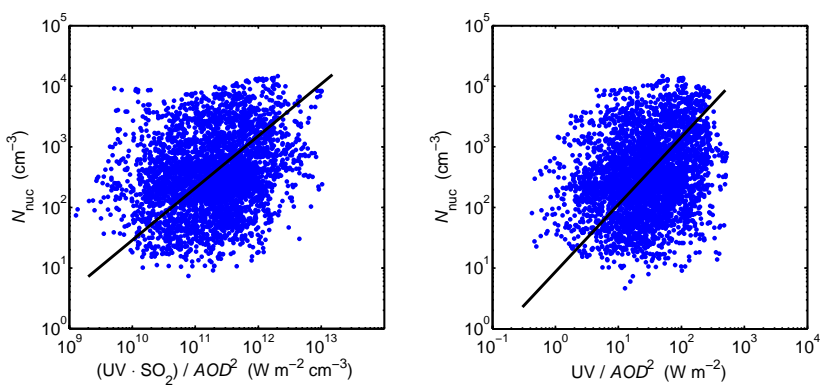

Fig. 2. Same as Fig. 1, but with CS replaced with AOD. Left: $\log (y)=0.86 \times \log (x)-7.141(r=0.25, p<0.001)$; Right: $\log (y)=1.11 \times \log (x)+0.94(r=0.23, p<0.001)$.

\subsection{Preliminary predictions for the global troposphere}

$\mathrm{SO}_{2}$ and $\mathrm{NO}_{2}$ concentrations are available from satellitebased spectrometers such as SCIAMACHY, GOME-2, TOMS, and OMI. The Total Ozone Mapping Spectrometers (TOMS) onboard several satellite platforms followed up by Ozone Monitoring Instruments (OMI) have provided a UV data record of more than $30 \mathrm{yr}$. In our analysis we use monthly data of OMI UV irradiance at $310 \mathrm{~nm}$ from the year 2006. The primary aerosol products from the MODIS instruments aboard the Terra and Aqua satellites are the AOD and the fine aerosol weighting (FW) at a wavelength of $550 \mathrm{~nm}$. The spatial resolution is $10 \times 10 \mathrm{~km}^{2}$. In our analysis we used the monthly mean satellite data available from the GIOVANNI website (http://disc.sci.gsfc.nasa.gov/). Both the MODIS AOD (e.g. Levy et al., 2010) and the OMI UV (e.g. Tanskanen et al., 2007) products have been extensively validated against ground-based measurements.

To begin with, we investigate whether column $\mathrm{SO}_{2}$ retrievals could be used with our proxies despite the detection limit for this compound by satellites. For this purpose we calculated three-month average $\mathrm{SO}_{2}$ concentration fields from the satellite data. The concentrations were close to zero, including also negative values, and without any clear and justified large-scale geographical patterns (Fig. 3). Therefore, in our subsequent proxy analysis only satellite-derived UV and AOD data are used.

Figure 4 shows the proxy constructed according to Eq. (9) with the two main assumptions considered in the previous section, i.e. CS replaced with $\mathrm{AOD}$ and $\left[\mathrm{SO}_{2}\right]$ assumed to be constant. We do not include the influence of $\mathrm{SO}_{2}$ variations for the reasons explained above. Four different seasons are shown: December-February (DJF), March-May (MAM), June-August (JJA), and September-November (SON). Our proxy predicts that the Southern Hemisphere is the dominating source for nucleation mode aerosol particles during DJF and MAM, whereas the Northern Hemisphere dominates during JJA. During SON, active regions for nucleation are predicted for both hemispheres. The relative importance of AOD and UV radiation in causing the seasonal cycle of the

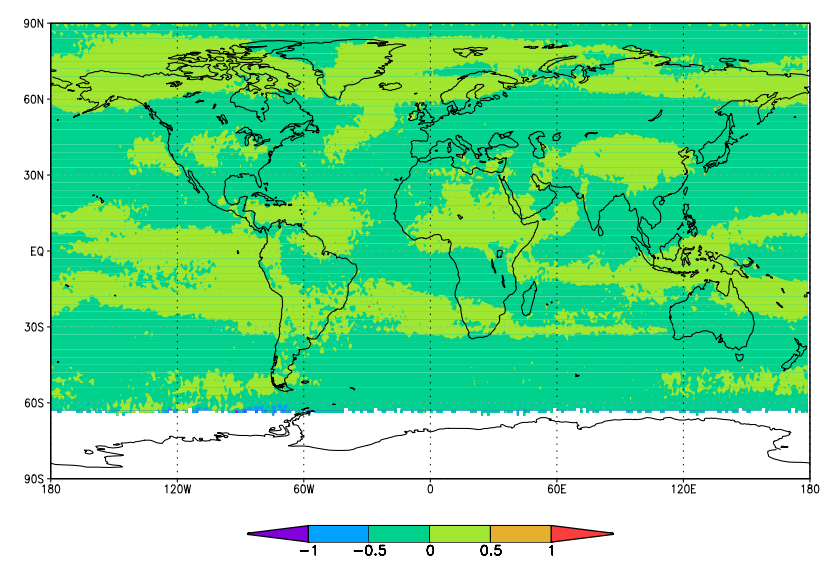

Fig. 3. $\mathrm{SO}_{2}$ Column Amount (Middle Troposphere) from OMI L2G product in Dobson Units for June, July and August in 2006. The color scale has been restricted; the lowest and highest spots are close to -2 and 2 , respectively.

proxy varies geographically depending on the latitude, which determines the variability of the UV radiation intensity, and how the main aerosol source and sinks behave annually.

Many of the patterns shown in Fig. 4 are qualitatively consistent with field observations and our current understanding on atmospheric nucleation (e.g. Kulmala et al., 2004; Kerminen et al., 2010). These include the extremely frequent and strong nucleation taking place over South Africa throughout the year (Vakkari et al., 2011), active yet less intensive nucleation observed over the boreal forest areas during the summer part of the Northern Hemisphere (Tunved et al., 2006; Dal Maso et al., 2008), and frequent nucleation taking place in the South-East Australian rainforest during most parts of the year (Suni et al., 2008). Field measurements show relatively frequent nucleation taking place over many parts of Central and Southern Europe almost throughout the year (Jaatinen et al., 2009; Manninen et al., 2010), over the North-Eastern United States outside the winter period (Stanier et al., 2004; Qian et al., 2007; Pryor et al., 2010), as well as in Beijing, China (Wu et al., 2007). Our proxy captures some of these features but totally fails in case of China. A possible reason for this is the very high $\mathrm{SO}_{2}$ concentration, and thereby very active role of it, in nucleation taking place over polluted regions of China. Finally, our proxy predicts very high nucleation mode particle number concentrations over large areas in Eastern South America and in some parts of the Amazon Basin. While there are practically no field data to confirm whether the pattern predicted for Eastern South America is correct or not, measurements conducted in the Amazon Basin show little evidence for near-surface regional-scale nucleation (Ahlm et al., 2009; Martin et al., 2010). The discrepancies between the proxy predictions and existing observations in the Amazon Basin, if real, might be related to too low $\mathrm{SO}_{2}$ concentrations to initiate nucleation there (Martin et al., 2010). Such a feature is not captured by a proxy assuming 

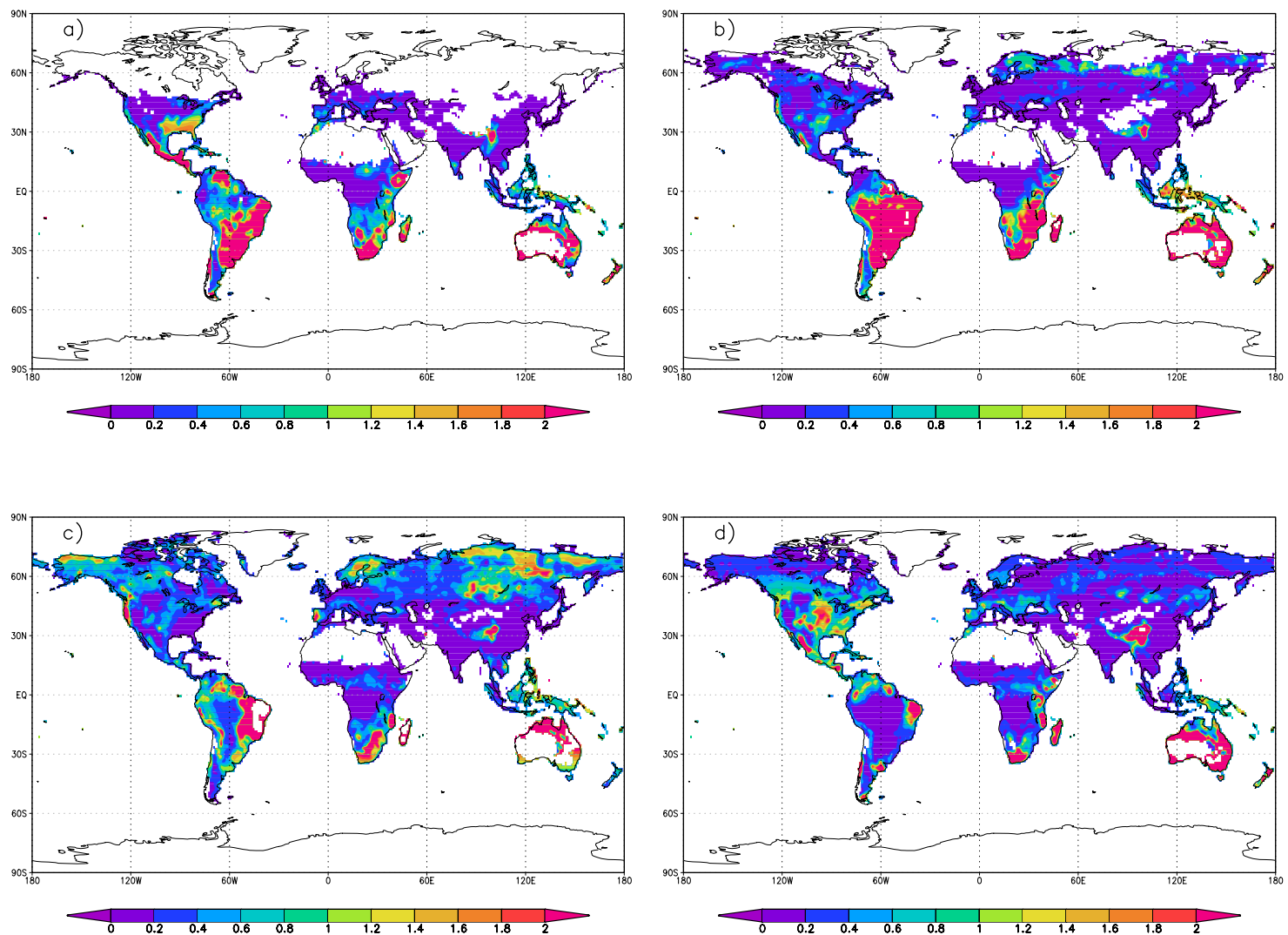

Fig. 4. The global distribution of the proxy given by Eq. (9), after replacing CS with AOD and assuming $\mathrm{SO}_{2}$ concentration to be constant, for the different seasons of the year 2006: DJF (a), MAM (b), JJA (c), and SON (d). The unit of UV is $\mathrm{mW} \mathrm{m}^{-2} \mathrm{~nm}^{-1}$, AOD is unitless. Moreover, UV/AOD ${ }^{2}$ is normalized by a factor of 10000 and the color scale is restricted to between 0 and 2 , in order to better show the geographical patterns.

a constant $\mathrm{SO}_{2}$ concentration. Besides field measurements, Fig. 4 shows many similarities to global model simulations made with a nucleation mechanism that is consistent with the proxy given by Eq. (9) (Spracklen et al., 2006).

Figure 5 shows an example of the proxy for primary nucleated particles (Eq. 13). The most significant concentrations are predicted over the polluted regions in South Africa, which would add to active regional nucleation predicted for this region. This is consistent with observations (Vakkari et al., 2011), even though the relative importance of regional and primary nucleation may be difficult to separate from field measurements. Our proxy does not predict any primary nucleation over the polluted regions of China which, again, might be due to the important role of $\mathrm{SO}_{2}$ in driving nucleation there.

\section{Concluding remarks}

We have derived proxies based on physical processes to estimate the concentration of nucleation mode particles. The proxies given by Eqs. (9) to (12) describe nucleation mode particle concentrations resulting from regional-scale

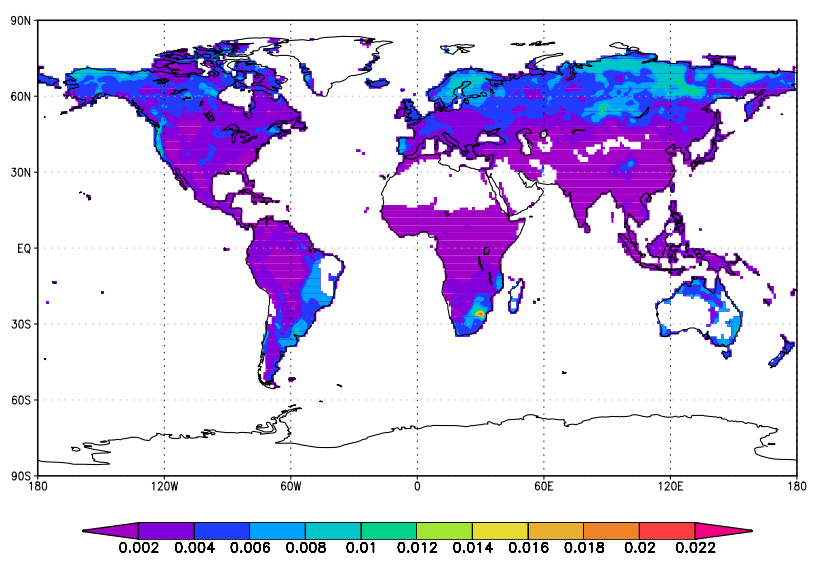

Fig. 5. The proxy given by Eq. (13) for the JJA season of the year 2006. The unit of $\mathrm{NO}_{2}$ is $10^{15}$ molec $\mathrm{cm}^{-2}$, AOD is unitless. Moreover, $\mathrm{NO}_{2}$ /AOD is normalized by a factor of 10000 . 
atmospheric new particle formation, whereas the proxies given by Eqs. (13) and (14) describe the contribution of direct emissions of nucleation mode particles (primary nuclei). When applied to satellite data, further simplifications in proxies are currently needed, such as replacing the condensation sink (CS) with the aerosol optical depth (AOD) and neglecting the influence of sulfur dioxide $\left(\mathrm{SO}_{2}\right)$ concentration variations or organic compounds on the nucleation rate.

The global pattern of nucleation mode particle number concentration predicted by satellite data had similarities to both observations and global model simulations, but revealed also several problems associated with our current approach. Problems were evident in regions where the nucleation rate is apparently sensitive to the $\mathrm{SO}_{2}$ concentration level, such as the polluted areas of China and regions with very low $\mathrm{SO}_{2}$ concentrations. Other problematic locations seem to be those having a significant contribution from primary nuclei associated with either $\mathrm{NO}_{2}$ or $\mathrm{SO}_{2}$ emissions. Furthermore, our current proxies cannot properly take into account the influence of organic compounds on nucleation and subsequent particle growth.

In order to be able to improve our results, more sophisticated products from satellite data are clearly needed. The present products like column $\mathrm{NO}_{2}$ concentration, and even more so the column $\mathrm{SO}_{2}$ concentration, are not good enough to distinguish any details in non- or less-polluted conditions. The satellite proxies would definitely benefit from having an explicit relation between CS and AOD that would take into account the influence of mixed layer height, the relative role of coarse and fine particles on CS and AOD, and the presence of potential aerosol layers aloft. More work is clearly needed in which satellite retrieval of organic compounds is combined with new information from in situ field experiments. The use of satellite products such as the UV actinic flux would be better than the surface irradiance used here. Currently such a data product is not available.

One should also explore the possibility to combine satellite data with information obtained from global or regional model simulations, as has been done in some other applications (see Sect. 1). An evident example in this regard would be to use some sort of time-averaged $\mathrm{SO}_{2}$ concentration field predicted by a global chemical transport model when applying the proxies 9 or 10 in different regions and at different times of the year. Model simulations might also be helpful in searching for a useful linkage between CS and AOD, or in attempting to include the influence of organic compounds on proxy predictions.

With our proxy method we have been able to significantly contribute to the application of satellite data to obtain information on aerosol dynamics in the global atmosphere. In future when this approach will be developed further and evaluated properly against long-term field observations, this knowledge might be utilized in global climate studies and in identifying new regions where continuous ground-based measurements should be started.
Acknowledgements. This research has received funding from ERC Advanced Grant "ATMNUCLE" no. 227463, the Academy of Finland Center of Excellence program (project no. 1118615), and the ESA Contract no. 4200023053/10/I-LG, STSE-ALANISAtmosphere-Land Interactions Study Theme 3: Aerosols.

Edited by: A. Laaksonen

\section{References}

Ahlm, L., Nilsson, E. D., Krejci, R., Mårtensson, E. M., Vogt, M., and Artaxo, P.: Aerosol number fluxes over the Amazon rain forest during the wet season, Atmos. Chem. Phys., 9, 9381-9400, doi:10.5194/acp-9-9381-2009, 2009.

Anderson, H. R.: Air pollution and mortality: A history, Atmos. Environ., 43, 142-152, 2009.

Andreae, M. O.: Correlation between cloud condensation nuclei concentration and aerosol optical thickness in remote and polluted regions, Atmos. Chem. Phys., 9, 543-556, doi:10.5194/acp-9-543-2009, 2009.

Arneth, A., Unger, N., Kulmala, M., and Andreae, M. O.: Clean the air, heat the planet, Science, 326, 672-673, 2009.

Arneth, A., Harrison, S. P., Zaehle, S., Tsigaridis, K., Menon, S., Bartlein, B. J., Feichter, J., Korhola, A., Kulmala, M., O'Donnell, D., Schurgers, G., Sorvari, S., and Vesala, T.: Terrestrial biogeochemical feedbacks in the climate system, Nat. Geosci., 3, 525-535, doi:10.1038/NGEO905, 2010.

Brasseur, G. P. and Broecner, E.: Impact of improved air quality on the future evolution of climate, Geophys. Res. Lett., 32, L23704, doi:10.1029/2005GL023902, 2005.

Dal Maso, M., Sogacheva, L., Anisimov, M. P., Arshinov, M., Baklanov, A., Belan, B., Khodzher, T. V., Obolkin, V. A., Staroverova, A., Vlasov, A., Zagaynov, V. A., Lushnikov, A., Lyubovtseva, Y. S., Riipinen, I., Kerminen, V.-M., and Kulmala, M.: Aerosol particle formation events at two Siberian stations inside the boreal forest, Boreal Env. Res., 13, 81-92, 2008.

de Leeuw, G., Kinne, S., Leon, J. F., Pelon, J., Rosenfeld, D., Schaap, M., Veefkind, P. J., Veihelmann, B., Winker D. M., and von Hoyningen-Huene W.: Retrieval of aerosol properties, in: The Remote Sensing of Tropospheric Composition from Space, Physics of Earth and Space Environments, edited by: Burrows, J. P., Platt, U., and Borrell, P., doi:10.1007/978-3-642-14791-3, Springer-Verlag, Berlin, Heidelberg, Germany, 2011.

Fernández-Camacho, R., Rodríguez, S., de la Rosa, J., Sánchez de la Campa, A. M., Viana, M., Alastuey, A., and Querol, X.: Ultrafine particle formation in the inland sea breeze airflow in Southwest Europe, Atmos. Chem. Phys., 10, 9615-9630, doi:10.5194/acp-10-9615-2010, 2010.

Forster, P., Ramaswamy, V., Artaxo, P., Berntsen, T., Betts, R., Fahey, D. W., Haywood, J., Lean, J., Lowe, D. C., Myhre, G., Nganga, J., Prinn, R., Raga, G., Schulz, M., and Van Dorland, R.: Changes in Atmospheric Constituents and in Radiative Forcing, in: Climate Change 2007: The Physical Science Basis, Contribution of Working Group I to the Fourth Assessment Report of the Intergovernmental Panel on Climate Change, edited by: Solomon, S., Qin, D., Manning, M., Chen, Z., Marquis, M., Avery, K. B., Tignor, M., and Miller, H. L., Cambridge University Press. Cambridge, United Kingdom and New York, NY, USA, 2007. 
Gu, L., Baldocchi, S. B., Verma, T. A., Black, T., Vesala, T., Falge, E., M., and Dowty, P. R.: Advantages of diffuse radiation for terrestrial ecosystem productivity, J. Geophys. Res., 107, 4050, doi:10.1029/2001JD001242, 2002.

Hand, J. L. and Malm, W. C.: Review of aerosol mass scattering efficiencies from ground-based measurements since 1990, J. Geophys. Res., 112, D16203, doi:10.1029/2007JD008484, 2007.

Hao, L. Q., Yli-Pirilä, P., Tiitta, P., Romakkaniemi, S., Vaattovaara, P., Kajos, M. K., Rinne, J., Heijari, J., Kortelainen, A., Miettinen, P., Kroll, J. H., Holopainen, J. K., Smith, J. N., Joutsensaari, J., Kulmala, M., Worsnop, D. R., and Laaksonen, A.: New particle formation from the oxidation of direct emissions of pine seedlings, Atmos. Chem. Phys., 9, 8121-8137, doi:10.5194/acp9-8121-2009, 2009.

Hari, P. and Kulmala, M.: Station for Measuring EcosystemAtmosphere Relations (SMEAR II), Boreal Env. Res., 10, 315322, 2005.

Hoff, R. M. and Christopher, S. A.: Remote sensing of particulate pollution from space: have we reached the promised land, J. Air Waste Manage. Assoc., 59, 645-675, 2009.

Holben, B., Eck, T. F., Slutsker, I., Tanre, D., Buis, J. P., Setzer, A., Vermote, E., Reagan, J. A., Kaufman, Y. J., Nakajima, T., Lavenu, F., Jankowiak, I., and Smirnov, A.: AERONET - a federated instrument network and data archive for aerosol characterization, Remote Sens. Environ., 66, 1-16, 1998.

Jaatinen, A., Hamed, A., Joutsensaari, J., Mikkonen, S., Birmili, W., Wehner, B., Spindler, G., Wiedensohler, A., Decesari, S., Mircea, M., Facchini, M. C., Junninen, H., Kulmala, M., Lehtinen, K. E. J., and Laaksonen, A.: A comparison of new particle formation events in the boundary layer at three different sites in Europe, Boreal Env. Res., 14, 481-498, 2009.

Jacob, D. and Winner, D. A.: Effect of climate change on air quality, Atmos. Environ., 43, 51-63, 2009.

Kazil, J., Stier, P., Zhang, K., Quaas, J., Kinne, S., O’Donnell, D., Rast, S., Esch, M., Ferrachat, S., Lohmann, U., and Feichter, J.: Aerosol nucleation and its role for clouds and Earth's radiative forcing in the aerosol-climate model ECHAM5-HAM, Atmos. Chem. Phys., 10, 10733-10752, doi:10.5194/acp-1010733-2010, 2010.

Kahn, R. A., Li, W.-H., Moroney, C., Diner, D. J., Martonchik, J. V., and Fishbein, E.: Aerosol source plume physical characteristics from space-based multiangle imaging, J. Geophys. Res., 112, D11205, doi:10.1029/2006JD007647, 2007.

Kahn, R. A., Chewng, Y., Nelson, D. L., Leung, F.-Y., Li, Q., Diner D. J., and Logan, J. A.: Geophys. Res. Lett., 35, L04809, doi:10.1029/2007GL032165, 2008.

Kerminen, V.-M., Lehtinen, K. E. J., Anttila, T., and Kulmala, M.: Dynamics of atmospheric nucleation mode particles: A time scale analysis, Tellus B, 56, 135-146, 2004.

Kerminen, V.-M., Lihavainen, H., Komppula, M., Viisanen, Y., and Kulmala, M.: Direct observational evidence linking atmospheric aerosol formation and cloud droplet activation, Geophys. Res. Lett. 32, L14803, doi:10.1029/2005GL023130, 2005.

Kerminen, V.-M., Petäjä, T., Manninen, H. E., Paasonen, P., Nieminen, T., Sipilä, M., Junninen, H., Ehn, M., Gagné, S., Laakso, L., Riipinen, I., Vehkamäki, H., Kurten, T., Ortega, I. K., Dal Maso, M., Brus, D., Hyvärinen, A., Lihavainen, H., Leppä, J., Lehtinen, K. E. J., Mirme, A., Mirme, S., Hõrrak, U., Berndt, T., Stratmann, F., Birmili, W., Wiedensohler, A., Metzger, A., Dom- men, J., Baltensperger, U., Kiendler-Scharr, A., Mentel, T. F., Wildt, J., Winkler, P. M., Wagner, P. E., Petzold, A., Minikin, A., Plass-Dülmer, C., Pöschl, U., Laaksonen, A., and Kulmala, M.: Atmospheric nucleation: highlights of the EUCAARI project and future directions, Atmos. Chem. Phys., 10, 10829-10848, doi:10.5194/acp-10-10829-2010, 2010.

Kokhanovsky, A. and de Leeuw, G.: Satellite Aerosol Remote Sensing Over Land, Springer, Berlin, Germany, 2009.

Kroll, J. H. and Seinfeld, J. H.: Chemistry of secondary organic aerosol: Formation and evolution of low-volatility organis in the atmosphere, Atmos. Environ., 42, 3593-3624, 2008.

Kuang, C., McMurry, P. H., McCormick, A. V., and Eisele, F., L.: Dependence of nucleation rates on sulfuric acid vapor concentration in diverse atmospheric locations, J. Geophys. Res., 113, D10209, doi:10.1029/2007JD009253, 2008.

Kulmala, M. and Kerminen, V.-M.: On the formation and growth of atmospheric nanoparticles, Atmos. Res., 90, 132-150, 2008.

Kulmala, M., Dal Maso, M., Mäkelä, J. M., Pirjola, L., Väkevä, M., Aalto, P. P., Miikkulainen, P., Hämeri, K., and O'Dowd, C. D.: On the formation, growth and composition of nucleation mode particles, Tellus B, 53, 479-490, 2001.

Kulmala, M. Vehkamäki, H., Petäjä, T., Dal Maso, M., Lauri, A., Kerminen, V.-M., Birmili, W., and McMurry, P. H.: Formation and growth rates of ultrafine atmospheric particles: a review of observations. J. Aerosol Sci., 35, 143-176, 2004.

Kulmala, M., Lehtinen, K. E. J., and Laaksonen, A.: Cluster activation theory as an explanation of the linear dependence between formation rate of $3 \mathrm{~nm}$ particles and sulphuric acid concentration, Atmos. Chem. Phys., 6, 787-793, doi:10.5194/acp-6-787-2006, 2006.

Kulmala, M., Riipinen, I., Nieminen, T., Hulkkonen, M., Sogacheva, L., Manninen, H. E., Paasonen, P., Petäjä, T., Dal Maso, M., Aalto, P. P., Viljanen, A., Usoskin, I., Vainio, R., Mirme, S., Mirme, A., Minikin, A., Petzold, A., Hõrrak, U., Plaß-Dülmer, C., Birmili, W., and Kerminen, V.-M.: Atmospheric data over a solar cycle: no connection between galactic cosmic rays and new particle formation, Atmos. Chem. Phys., 10, 1885-1898, doi:10.5194/acp-10-1885-2010, 2010.

Laakso, L., Petäjä, T., Lehtinen, K. E. J., Kulmala, M., Paatero, J., Hõrrak, U., Tammet, H., and Joutsensaari, J.: Ion production rate in a boreal forest based on ion, particle and radiation measurements, Atmos. Chem. Phys., 4, 1933-1943, doi:10.5194/acp-41933-2004, 2004.

Laaksonen, A., Hamed, A., Joutsensaari, J., Hiltunen, L., Cavalli, F., Junkermann, W., Asmi, A., Fuzzi, S., and Facchini, M. C.: Cloud condensation nuclei production from nucleation events at a highly polluted region, Geophys. Res. Lett., 32, L06812, doi:10.1029/2004GL022092, 2005.

Lamsal, L. N., Martin, R. V., Padmanabhan, A., van Donkelaar, A., Zhang, Q., Sioris, C. E., Change, K., Kusosu, T. P., and Newchurch, M. J.: Application of satellite observations for timely updates to global anthropogenic $\mathrm{NO}_{\mathrm{x}}$ emission inventories, Geophys. Res. Lett., 38, L05810, doi:10.1029/2010GL046476, 2011.

Lee, C., Martin, R. V., van Donkelaar, A., Lee, H., Dickerson, R. R., Hains, J. C., Krotkov, N., Richter, A., Vinnikov, K., and Schwab, J. J.: $\mathrm{SO}_{2}$ emissions and lifetimes: Estimates from inverse modelin using in situ and global, space-based (SCIAMACHY and OMI) observations, J. Geophys. Res., 116, 
D063304, doi:10.1029/2010JD014758, 2011.

Lehtinen, K. E. J., Dal Maso, M., Kulmala, M., and Kerminen, V.M.: Estimating nucleation rates from apparent particle formation rates and vice versa: Revised formulation of the KerminenKulmala equation, J. Aerosol Sci., 38, 988-994, 2007.

Levy, R. C., Remer, L. A., Kleidman, R. G., Mattoo, S., Ichoku, C., Kahn, R., and Eck, T. F.: Global evaluation of the Collection 5 MODIS dark-target aerosol products over land, Atmos. Chem. Phys., 10, 10399-10420, doi:10.5194/acp-10-10399-2010, 2010.

Lihavainen, H., Kerminen, V.-M., Komppula, M., Hatakka, J., Aaltonen, V., Kulmala, M., and Viisanen, Y.: Production of "potential" cloud condensation nuclei associated with atmospheric new-particle formation in northern Finland, J. Geophys. Res., 108, 4782, doi:10.1029/2003JD003887, 2003.

Luo, G. and Yu, F.: Sensitivity of global cloud condensation nuclei concentrations to primary sulfate emission parameterizations, Atmos. Chem. Phys., 11, 1949-1959, doi:10.5194/acp-111949-2011, 2011.

Makkonen, R., Asmi, A., Korhonen, H., Kokkola, H., Järvenoja, S., Räisänen, P., Lehtinen, K. E. J., Laaksonen, A., Kerminen, V.M., Järvinen, H., Lohmann, U., Bennartz, R., Feichter, J., and Kulmala, M.: Sensitivity of aerosol concentrations and cloud properties to nucleation and secondary organic distribution in ECHAM5-HAM global circulation model, Atmos. Chem. Phys., 9, 1747-1766, doi:10.5194/acp-9-1747-2009, 2009.

Manninen, H. E., Nieminen, T., Asmi, E., Gagné, S., Häkkinen, S., Lehtipalo, K., Aalto, P., Vana, M., Mirme, A., Mirme, S., Hõrrak, U., Plass-Dülmer, C., Stange, G., Kiss, G., Hoffer, A., Töro, N., Moerman, M., Henzing, B., de Leeuw, G., Brinkenberg, M., Kouvarakis, G. N., Bougiatioti, A., Mihalopoulos, N., O’Dowd, C., Ceburnis, D., Arneth, A., Svenningsson, B., Swietlicki, E., Tarozzi, L., Decesari, S., Facchini, M. C., Birmili, W., Sonntag, A., Wiedensohler, A., Boulon, J., Sellegri, K., Laj, P., Gysel, M., Bukowiecki, N., Weingartner, E., Wehrle, G., Laaksonen, A., Hamed, A., Joutsensaari, J., Petäjä, T., Kerminen, V.-M., and Kulmala, M.: EUCAARI ion spectrometer measurements at 12 European sites - analysis of new particle formation events, Atmos. Chem. Phys., 10, 7907-7927, doi:10.5194/acp-10-79072010, 2010.

Martin, R. V.: Satellite remote sensing and surface air quality, Atmos. Environ., 42, 7823-7843, 2008.

Martin, S. T., Andreae, M. O., Artaxo, P., Baumgardner, D., Chen, Q., Goldstein, A. G., Guenther, A., Heald, C. L., Mayol-Bracero, O. L., McMurry, P. H., Pauliquevis, T., Pösschl, U., Prather, K. A., Roberts, G. C., Saleska, S. R., Silva Dias, M. A., Spracklen, D. V., Swietlicki, E., and Trebs, I.: Sources and properties of Amazonian aerosol particles, Rev. Geophys., 48, RG2002, doi:10.1029/2008RG000280, 2010.

McMurry, P. H. and Friedlander, S. K.: New particle formation in the presence of aerosols, Atmos. Environ., 13, 1635-1651, 1979.

Merikanto, J., Spracklen, D. V., Mann, G. W., Pickering, S. J., and Carslaw, K. S.: Impact of nucleation on global CCN, Atmos. Chem. Phys., 9, 8601-8616, doi:10.5194/acp-9-8601-2009, 2009.

Merikanto, J., Spracklen, D. V., Pringle, K. J., and Carslaw, K. S.: Effects of boundary layer particle formation on cloud droplet number and changes in cloud albedo from 1850 to 2000, Atmos. Chem. Phys., 10, 695-705, doi:10.5194/acp-10-695-2010, 2010.

Metzger, A., Verheggen, B., Dommen, J., Duplissy, J., Prevot,
A. S., Weingartner, E., Riipinen, I., Kulmala, M., Spracklen, D. V., Carslaw, K. S., and Baltensperger, U.: Evidence for the role of organics in aerosol particle formation under atmospheric conditions, P. Natl. Acad. Sci., 107, 6646-6651, doi:10.1073/pnas.0911330107, 2010.

Myhre, G.: Consistency between satellite derived and modeled estimates of the direct aerosol effect, Science, 325, 187-190, 2009.

Muller, J.-P., Denis, M.-A., Dundas, R. D., Mitchell, K. L., Naud, C., and Mannstein, H.: Stereo cloud-top heights and cloud fraction retrieval from ATSR-2, Int. J. Remote Sensing, 28, 19211938, 2007.

Nieminen, T., Manninen, H. E., Sihto, S.-L., Yli-Juuti, T., Mauldin III, R. L., Petäjä, T., Riipinen, I., Kerminen, V.-M., and Kulmala, M.: Connection of sulfuric acid to atmospheric nucleation in boreal forest, Environ. Sci. Technol., 43, 4715-4721, 2009.

O'Dowd, C. D., Monahan, C., and Dall'Osto, M.: On the occurrence of opean ocean particle production and growth events, Geophys. Res. Lett., 37, L19805, doi:10.1029/2010GL044679, 2010.

Paasonen, P., Nieminen, T., Asmi, E., Manninen, H. E., Petäjä, T., Plass-Dülmer, C., Flentje, H., Birmili, W., Wiedensohler, A., Hõrrak, U., Metzger, A., Hamed, A., Laaksonen, A., Facchini, M. C., Kerminen, V.-M., and Kulmala, M.: On the roles of sulphuric acid and low-volatility organic vapours in the initial steps of atmospheric new particle formation, Atmos. Chem. Phys., 10, 11223-11242, doi:10.5194/acp-10-11223-2010, 2010.

Petäjä, T., Mauldin, III, R. L., Kosciuch, E., McGrath, J., Nieminen, T., Paasonen, P., Boy, M., Adamov, A., Kotiaho, T., and Kulmala, M.: Sulfuric acid and $\mathrm{OH}$ concentrations in a boreal forest site, Atmos. Chem. Phys., 9, 7435-7448, doi:10.5194/acp9-7435-2009, 2009.

Philippin, S., Laj, P., Putaud, J.-P., Wiedensohler, A., de Leeuw, G., Fjaeraa, A. M., Platt, U., Baltensperger, U., and Fiebig, M.: EUSAAR - An Unprecedented Network of Aerosol Observation in Europe. Earozoru Kenkyu, JAAST, 24(2), 78-83, 2009.

Pierce, J. R. and Adams, P. J.: Uncertainty in global CCN concentrations from uncertain aerosol nucleation and primary emission rates, Atmos. Chem. Phys., 9, 1339-1356, doi:10.5194/acp-91339-2009, 2009.

Pope, C. A. and Dockery, D. W.: Health effects of fine particulate air pollution: lines that connect, J. Air Waste Manage. Assoc., 56, 709-742, 2006.

Pryor, S. C., Spaulding, A. M., and Barthelmie, R. J.: New particle formation in the Midwestern USA: Event characteristics, meteorological context and vertical profiles, Atmos. Environ., 44, 4413-4425, 2010.

Qian, S., Sakurai, H., and McMurry, P. H.: Characteristics of regional nucleation events in urban East St. Louis, Atmos. Environ., 41, 4119-4127, 2007.

Quaas, J., Ming, Y., Menon, S., Takemura, T., Wang, M., Penner, J. E., Gettelman, A., Lohmann, U., Bellouin, N., Boucher, O., Sayer, A. M., Thomas, G. E., McComiskey, A., Feingold, G., Hoose, C., Kristjánsson, J. E., Liu, X., Balkanski, Y., Donner, L. J., Ginoux, P. A., Stier, P., Grandey, B., Feichter, J., Sednev, I., Bauer, S. E., Koch, D., Grainger, R. G., Kirkevåg, A., Iversen, T., Seland, Ø., Easter, R., Ghan, S. J., Rasch, P. J., Morrison, H., Lamarque, J.-F., Iacono, M. J., Kinne, S., and Schulz, M.: Aerosol indirect effects - general circulation model intercomparison and evaluation with satellite data, Atmos. Chem. Phys., 
9, 8697-8717, doi:10.5194/acp-9-8697-2009, 2009.

Raes, F., Liao, H., Chen, W.-T., and Seinfeld, J. H.: Atmospheric chemistry-climate feedbacks, J. Geophys. Res., 115, D12121, doi.10.1029/2009JD013300, 2010.

Riipinen, I., Sihto, S.-L., Kulmala, M., Arnold, F., Dal Maso, M., Birmili, W., Saarnio, K., Teinilä, K., Kerminen, V.-M., Laaksonen, A., and Lehtinen, K. E. J.: Connections between atmospheric sulphuric acid and new particle formation during QUEST III-IV campaigns in Heidelberg and Hyytiälá, Atmos. Chem. Phys., 7, 1899-1914, doi:10.5194/acp-7-1899-2007, 2007.

Rohrer, F. and Berresheim, H.: Strong correlation between levels of tropospheric hygroxyl radicals solar ultraviolet radiation, Nature, 442, 184-187, 2006.

Sipilä, M., Berndt, T., Petäjä, T., Brus, D., Vanhanen, J., Stramann, F., Patokoski, J., Mauldin III, R. L., Hyvärinen, A.P., Lihavainen, H., and Kulmala, M.: The role of sulfuric acid in atmospheric nucleation, Science 327, 1243-1246, doi:10.1126/science.1180315, 2010.

Spracklen, D. V., Carslaw, K. S., Kulmala, M., Kerminen, V.-M., Mann, G. W., and Sihto, S.-L.: The contribution of boundary layer nucleation events to total particle concentrations on regional and global scales, Atmos. Chem. Phys., 6, 5631-5648, doi:10.5194/acp-6-5631-2006, 2006.

Spracklen, D. V., Carslaw, K. S., Kulmala, M., Kerminen, V.-M., Sihto, S.-L., Riipinen, I., Merikanto, J., Mann, G. W., Chipperfield, M. P., Wiedensohler, A., Birmili, W., and Lihavainen, H.: Contribution of particle formation to global cloud condensation nuclei concentrations, Geophys. Res. Lett., 35, L06808, doi:10.1029/2007GL033038, 2008.

Spracklen, D. V., Carslaw, K. S., Merikanto, J., Mann, G. W., Reddington, C. L., Pickering, S., Ogren, J. A., Andrews, E., Baltensperger, U., Weingartner, E., Boy, M., Kulmala, M., Laakso, L., Lihavainen, H., Kivekäs, N., Komppula, M., Mihalopoulos, N., Kouvarakis, G., Jennings, S. G., O’Dowd, C., Birmili, W., Wiedensohler, A., Weller, R., Gras, J., Laj, P., Sellegri, K., Bonn, B., Krejci, R., Laaksonen, A., Hamed, A., Minikin, A., Harrison, R. M., Talbot, R., and Sun, J.: Explaining global surface aerosol number concentrations in terms of primary emissions and particle formation, Atmos. Chem. Phys., 10, 4775-4793, doi:10.5194/acp-10-4775-2010, 2010.

Stanier, C. O., Khlystov, A. Y., and Pandis, S. N.: Nucleation events during the Pittsburg Air Quality Study: Description and relation to key meteorological, gas phase, and aerosol parameters, Aerosol Sci. Technol., 38, 253-264, 2004.

Stavrakou, T., Müller, J.-F., De Smedt, I., Van Roozendael, M., van der Werf, G. R., Giglio, L., and Guenther, A.: Global emissions of non-methane hydrocarbons deduced from SCIAMACHY formaldehyde columns through 2003-2006, Atmos. Chem. Phys., 9, 3663-3679, doi:10.5194/acp-9-3663-2009, 2009.

Suni, T., Kulmala, M., Hirsikko, A., Bergman, T., Laakso, L., Aalto, P. P., Leuning, R., Cleugh, H., Zegelin, S., Hughes, D., van Gorsel, E., Kitchen, M., Vana, M., Hõrrak, U., Mirme, S., Mirme, A., Sevanto, S., Twining, J., and Tadros, C.: Formation and characteristics of ions and charged aerosol particles in a native Australian Eucalypt forest, Atmos. Chem. Phys., 8, 129-139, doi:10.5194/acp-8-129-2008, 2008.

Tanskanen, A., Lindfors, A., Määttä, A., Krotkov, N., Herman, J., Kaurola, J., Koskela, T., Lakkala, K., Fioletov, V., Bern- hard, G., McKenzie, R., Kondo, Y., O'Neill, M., Slaper, H., den Outer, P., Bais, A. F., and Tamminen, J.: Validation of daily erythemal doses from Ozone Monitoring Instrument with groundbased UV measurement data, J. Geophys. Res., 112, D24S44, doi:10.1029/2007JD008830, 2007.

Tunved, P., Hansson, H.-C., Kerminen, V.-M., Ström, J., Dal Maso, M., Lihavainen, H., Viisanen, Y., Aalto, P. P., Komppula, M., and Kulmala, M.: High natural aerosol loading over boreal forests, Science, 312, 261-263, 2006.

Vakkari, V., Laakso, H., Kulmala, M., Laaksonen, A., Mabaso, D., Molefe, M., Kgabi, N., and Laakso, L.: New particle formation events in semi-clean South African savannah, Atmos. Chem. Phys., 11, 3333-3346, doi:10.5194/acp-11-3333-2011, 2011.

Veefkind, J. P., Boersma, K. F., Wang, J., Kurosu, T. P., Krotkov, N., Chance, K., and Levelt, P. F.: Global satellite analysis of the relation between aerosols and short-lived trace gases, Atmos. Chem. Phys., 11, 1255-1267, doi:10.5194/acp-11-1255-2011, 2011.

Wiedensohler, A., Cheng, Y. F., Nowak, A., Wehner, B., Achtert, P., Berghof, M., Birmili, W., Wu, Z. J., Hu, M., Zhu, T., Takegawa, N., Kita, K., Kondo, Y., Lou, S. R., Hofzumahaus, A., Holland, F., Wahner,A., Gunthe, S. S., Rose, D., Su, H., and Pöschl, U.: Rapid aerosol particle growth and increase of cloud condensation nucleus activity by secondary aerosol formation and condensation: A case study for regional air pollution in northeastern China, J. Geophys. Res., 114, D00G08, doi:10.1029/2008JD010884, 2009.

Virkkula, A., Backman, J., Aalto, P. P., Hulkkonen, M., Riuttanen, L., Nieminen, T., dal Maso, M., Sogacheva, L., de Leeuw, G., and Kulmala, M.: Seasonal cycle, size dependencies, and source analyses of aerosol optical properties at the SMEAR II measurement station in Hyytiälä, Finland, Atmos. Chem. Phys., 11, 4445-4468, doi:10.5194/acp-11-4445-2011, 2011.

Vuollekoski, H., Kerminen, V.-M., Anttila, T., Sihto, S.-L., Vana, M., Ehn, M., Korhonen, H., McFiggans, G., O’Dowd, C. D., and Kulmala, M.: Iodine dioxide nucleation simulations in coastal and remote marine environments, J. Geophys. Res., 114, D02206, doi:10.1029/2008JD010713, 2009.

Wang, M. and Penner, J. E.: Aerosol indirect forcing in a global model with particle nucleation, Atmos. Chem. Phys., 9, 239-260, doi:10.5194/acp-9-239-2009, 2009.

Wang, K., Dickinson, R. E., and Liang, S.: Observational evidence on the effects of clouds and aerosols on net ecosystem exchange and evapotranspiration, Geophys. Res. Lett., 35, L10401, doi:10.1029/2008GL034167, 2008.

Wu, Z., Hu, M., Liu, S., Wehner, B., Bauer, S., Massling, A., Wiedensohler, A., Petäjä, T., Dal Maso, M., and Kulmala, M.: New particle formation in Beijing, China: Statistical analysis of a 1-year data set, J. Geophys. Res., 112, D09209, doi:10.1029/2006JD007406, 2007.

Yu, F. and Luo, G.: Simulation of particle size distribution with a global aerosol model: contribution of nucleation to aerosol and CCN number concentrations, Atmos. Chem. Phys., 9, 76917710, doi:10.5194/acp-9-7691-2009, 2009.

Yu, F., Luo, G., Bates, T. S., Anderson, B., Clarke, A., Kapustin, V., Yantosca, R. M., Wang, Y., and Wu, S.: Spatial distributions of particle number concentrations in the global troposphere: Simulations, observations, and implications for nucleation mechanisms, J. Geophys. Res., 115, D17205, doi:10.1029/2009JD013473, 2010. 